\title{
Optimizing BA and IBA Concentrations for Micro Propagation of Spineless Yucca (Yucca Elephantipes)
}

\author{
Abdullah S. Al. Johani and Bahget T. Hamooh \\ Arid Land Agriculture Department, Faculty of Meteorology, \\ Environment and Arid Land Agriculture, \\ King Abdulaziz University
}

\begin{abstract}
This study was conducted to optimize micropropagation of Spineless Yucca (Yucca elephantipes) using different concentrations of BAP and IBA concentrations in Murashige. Benzyl adenine (BA) was used in five concentrations $(0,1,2,3$ and $7 \mathrm{mg} / \mathrm{L})$ together with $0.5 \mathrm{mg} / \mathrm{L}$ NAA for shoot initiation and branching in apical buds, and IBA was also used in five concentrations $(0.0 .2,0.4$, 0.6 and $1 \mathrm{mg} / \mathrm{L}$ ) for rooting initiation. The experiments were layout in Randomized Complete design (CRD) using 5 replications. The results showed that $\mathrm{BA}$ retarded number of covered branches and increased number and length of the uncovered branches. The highest number of vegetative branches/shoots were 8.75 and 6.876 and observed with MS medium supplemented with $2 \mathrm{mg} / \mathrm{l}-1$ and $3 \mathrm{mg} / \mathrm{l}-1$ BA. Shoots length was significantly increased with suppling IBA to the medium at concentrations from 1-7 $\mathrm{mg} / \mathrm{l}-1$ and the average length of shoots ranged between 5.3 and $7.3 \mathrm{~cm}$. As for IBA root number and root length increased with increase in concentration from $0.2,0.4,0.6$ and $1 \mathrm{mg} / \mathrm{l}-1$, with the highest number of roots $(18 / \mathrm{shoot})$ and highest root length $(15.66 \mathrm{~cm})$ given by $1 \mathrm{mg} / \mathrm{l}-1$ concentration. It is recommended for initiation of vegetative uncovered branch numbers in apical buds of Yucca elephentipes plant to apply $B A$ at rate of up to 2-3 mg/l-1, and for branch length $B$ a concentration can rise up to $7 \mathrm{mg} / \mathrm{l}-1$, while for initiation of root numbers and length IBA can be applied up to $1 \mathrm{mg} / \mathrm{l}-1$.
\end{abstract}

Key words: Benzyl adenine (BA), indole buteric acid (IBA), Yucca elephentipes, micropropagation.

\section{INTRODUCTION}

Plant growth regulators are hormones that initiate and regulate growth in plants, and they are produced naturally by plants normally in shoot and root tips, and these hormones promote cell division and stem and root growth (Holganix, 2018). Plant growth regulators or auxins aid development of plant at all growth stages, from cellular level, to organs, and ultimately to the whole plant (Enders et al., 2015). Auxins cause changes in genes set up in the plant cells when these cells come into contact with these auxins, and regulation takes place in the genes and some genes come up and other genes come down, but the exact mechanisms of this gene arrangement is not fully understood and are still under study, and now there are two auxin signalling pathways (Leyser, 2018 and Enders et al., 2015). When considering cell levels, growth regulating hormones are essential for cell growth, and they affect both cell division and cellular expansion, and that growth regulating hormones concentration level, together with other factors, cause differentiation and specification of the cell (Benkova et al., 2003). There are receptors for auxins, and the most well characterized auxin receptors are the TIR1/ AFB family of F-box proteins, and when auxins and these proteins bind together the auxin acts as a molecular glue that allows these proteins to then bind to their targets (Enders et al. 2015). Auxin types of differentiations depend on the specific tissue, and it may promote axial elongation in shoots, or lateral expansion as in root swelling, or isodiametric expansion as in fruit growth, and sometimes auxin promote cellular expansion without cell division. In other cases cell expansion and cell division occur within the same tissue (root initiation, fruit growth (Friml, 2003). Action of auxin begins in the embryo of the plant, then extends to form buds which develop into organs, and it helps in proper coordination of the arising organs, such as roots, stems and leaves and mediates long distance signals between them, and in this way it contributes in the all mechanism of the plant (Friml, 2003). It is through auxins that plants know where to put their branches or thrir organs (Simon and Petrisek, 2011). Auxin stimulates cell elongation and cell division through stimulation of the wallloosening factors, such as elastins, which then facilitates loosen cell walls, and with presence of gibberellins the process will be more effective, and root initiation will take place in callus if auxin and cytokinin are applied to callus and the auxin concentration is higher than cytokinin concentration, and xylem tissues can be generated when the auxin concentration is equal to the cytokinins (Benkoval et al. 2003). Initiation and promotion of root growth is facilitated by auxins, and auxin induces growth in both preexisting roots and adventitious root or branching of the roots, and on transportation of more auxin from stem down to roots more stimulation of root occurs (Chambers, 1999). NAA and IBA auxins, are commonly applied to stimulate root initiation in rooting cuttings of plants In horticultural activities, and high concentrations of auxin inhibit root elongation and instead enhance adventitious root formation (Ludwig-Müller, 2011). The auxin (indole-3-acetic acid, IAA), which is produced in young shoot organs, promotes root development and induces vascular differentiation (Aloni et al.2006). When benzyl adenine (BA) was sprayed on cotton boll weight and fiber it increased cotton boll 
weight and fiber quality under both normal and low temperature conditions; and significantly increased the boll sucrose content and sucrose synthase and sucrose phosphate synthase activities (Wang et al., 2011). Plant Growth Regulator IBA treatment significantly inhibited germination of the seeds of the plant Pinguicula ionantha compared to other PGR treatments and the control (Annis et al. 2014). Under using of Murashige and Skoog (MS) medium with $8.87 \mu \mathrm{M}$ BA and $2.46 \mu \mathrm{M}$ indole-3-butyric acid (IBA) the number of shoots initiated from leaf and internode explants reached its highest numbers (76.0 and 90.8 shoots respectively, and calli subcultured onto medium supplemented with $8.87 \mu \mathrm{M}$ BA and $2.46 \mu \mathrm{M}$ IBA developed a mean of 20.1 shoots within 40 days, and it seems that N6-benzyladenine (BA) was the most effective cytokinin for the induction of shoots (Shahanaz, et al., 2007). The Plant Growth Regulator IBA significantly inhibited germination of the seeds of the plant Pinguicula ionantha compared to other PGR treatments and the control (Annis et al., 2014). The aim of this study is to investigate effect of benzyl adenine (BA) on shoot growth, and effect of indole-3-buteric acid (IBA) on root initiation of terminal buds and stems of Yucca elephantipes plant.

\section{MATERIALS AND METHODS}

\section{The plant materials:}

This study was conducted in the tissue culture laboratory of the Department of the Arid Land Agriculture, of the Faculty of Metreology, Environment and Arid Land Agriculture of King Abdulaziz University in Jeddah, Saudi Arabia. Apical buds were isolated by cutting using sterilized sharp knife at lengths of 3-4 cm from vegetative branches of Yucca elephantipes plants growing in pots. The terminal buds were washed carefully with tap water and cleaned from all debris and dust. Bud culture media: Murashige and Skoog (1962) (MS) medium was used for it is the best medium for bud differentiation. It contained the following:

\section{Inorganic nutrients:}

1 - Macro-nutrients: NH4NO3 (1650 mg / L), KNO3 (1900 $\mathrm{mg} / \mathrm{L}), \mathrm{CaCl} 2.7 \mathrm{H} 2 \mathrm{O}$ (440 mg / L), MgSO4.7H2O (37 mg / L), KH2PO4 (170 mg / L).

2 - Micronutrients: Boric acid H2BO3 (6.2 mg / L), manganese sukphate MgSO4.H2O (16.9 mg / L), zinc sulphate $\mathrm{ZnSO} 4.7 \mathrm{H} 2 \mathrm{O}(8.6 \mathrm{mg} / \mathrm{L})$, potassium iodid $\mathrm{KI}$ (0.83 mg / L), sodium molibdate Na2Mo4 (0.250 mg / L), copper sulphate $\mathrm{CuSO} 4.5 \mathrm{H} 2 \mathrm{O}(0.025 \mathrm{mg} / \mathrm{L})$, ferric sulphate FeSO4.7H2O (27.8 mg / L), sodium ethylene tetra acetate Na2EDTA $(37.3 \mathrm{mg} / \mathrm{L})$.

3 - Organic Supplements:

\section{1-Vitamins}

Inositol (100 mg / L), nicotinic acid $(0.5 \mathrm{mg} / \mathrm{L})$, pyridoxine HCI (0.5 mg / L), Thiamine-(0.4 mg / L),
Sucrose $(30000 \mathrm{mg} / \mathrm{L})$

pH 5.7

\section{Shoot tips multiplication:}

Benzyl adenine (BA) was added at 5 concentrations $(0,1,2$, 3 and $7 \mathrm{mg} / \mathrm{L}$ ). The treatments were replicated 8 times using randomized complete block design. Fixed naphthalic acid (NAA) at concentration of $(0.1 \mathrm{mg} / \mathrm{L})$ was added to each treatment. Then agar was added at rate of $7 \mathrm{mg} / \mathrm{L}$ with heating and stirring to be sure that all agar was dissolved. Then the nutritional media were distributed to all tissue culture growth tubs, $18 \mathrm{~cm}$ in length and $2 \mathrm{~cm}$ diameter, and after covering the tube with their contents were sterilized in autoclave at $121{ }^{\circ} \mathrm{C}$ and pressure of $0.05 \mathrm{~kg} / \mathrm{cm}$ for 15 minutes. The terminal buds were then sterilized by been put in $500 \mathrm{ml}$ flasks in distilled water, with $10 \%$ Clorox with 20 Tween for 20 minutes Then put in ethyl alcohol for 5 minutes, then washed carefully in Laminar air Flow Hood. Then put in a petri dish, each cut into 6-10 apicals for each bud with length of $0.5-1.0 \mathrm{~cm}$. The buds were put inside test tubes $25 \times 150 \mathrm{~mm}$ on the growth media for growing.

\section{Rooting experiments:}

The same procedure was followed for roots initiation in the plant stems with the use of indole-3-buteric acid (IBA) with five concentrations $(0,0.2,0.4,0.6$ and $1 \mathrm{mg} / \mathrm{L}$.$) .$

\section{RESULTS}

\section{Shoot tips multiplication:}

Normally different growth regulating hormones are added to the growth media of plant tissues of the apical buds, and its role is to enhance growth and to enrich and multiplication of these buds. The effect of five concentrations of the growth regulator benzyl adenine (BA) with fixed concentration of the growth regulator hormone NAA on multiplications of apical buds of Yucca elephantipes (Fig. 1). Table (1) effects of the hormone BA on the number of the uncovered vegetative branches and the number of covered vegetative branches, and the length of the vegetative branches of the plant Yucca elephantipes. There are significant differences $(\mathrm{P} \leq 0.01)$ between the different BA concentrations used on number and length of the vegetative branches covered and uncovered. The mean values of the numbers and length of covered and uncovered vegetative branches of Yucca elephantipes apical buds under the different BA concentrations show that the highest number of uncovered branches was obtained in the concentrations $0 \mathrm{mg} / \mathrm{L}$ with 10 branches, followed by the concentrations 1 and $7 \mathrm{mg} / \mathrm{L}$ with 4.375 and $5.00 \mathrm{mg} / \mathrm{L}$ respectively with no significant difference between them. The concentration $2 \mathrm{mg} / \mathrm{L}$ gave the least number of uncovered branches 1.25 and buds without BA gave zero branches. In the case of the covered branches concentration $2 \mathrm{mg} / \mathrm{L}$ gave significantly the highest branch number 8.750 branches, then concentration $3 \mathrm{mg} / \mathrm{L}$ with 6.875 branches, then concentration $1 \mathrm{mg} / \mathrm{L}$ with 5.625 covered branches, 
then concentration $7 \mathrm{mg} / \mathrm{L}$ with 5.00 branches and the 0 $\mathrm{mg} / \mathrm{L}$ concentration gave zero covered branches. Regarding the length of vegetative branches it varied between zero branches in the $0 \mathrm{BA} \mathrm{mg} / \mathrm{L}$ up to 7.3 branches in the treatment $2 \mathrm{mg} / \mathrm{L}$ with no significant differences between the treatments 1, 2, 3 and $4 \mathrm{mg}$ / L BA (Table 2).

TABLE 1. ANALYSIS OF VARIANCE BETWEEN THE DIFFERENT BA HORMONE CONCENTRATIONS ON NUMBER OF COVERED AND UNCOVERED VEGETATIVE BRANCHES AND THEIR LENGTH OF SPINELESS YUCCA PLANT

\begin{tabular}{|c|c|c|c|c|}
\hline Source of variance & DF & \multicolumn{3}{|c|}{ Average square deviation } \\
\cline { 3 - 5 } & & Uncovered vegetative branches & $\begin{array}{c}\text { Covered vegetative } \\
\text { branches }\end{array}$ & $\begin{array}{c}\text { Length of vegetative } \\
\text { branches (cm) }\end{array}$ \\
\hline $\begin{array}{c}\text { Between } \\
\text { treatments }\end{array}$ & 4 & $85.312^{* *}$ & $85.815^{* *}$ & $70.75^{* *}$ \\
\hline Standard error & 35 & 3.15 & 2.342 & 9.21 \\
\hline Total & 39 & & & \\
\hline
\end{tabular}

NS: Not significant at $\mathrm{P} \leq 0.05,{ }^{*}$ : significant at $\mathrm{P} \leq 0.05,{ }^{*}$ : significant at $\mathrm{P} \leq 0.01$

TABLE 2. MEANS OF NUMBER AND LENGTH OF COVERED AND UNCOVERED VEGETATIVE BRANCHES OF SPINELESS YUCCA PLANT UNDER DIFFERENT BA CONCENTRATIONS

\begin{tabular}{|c|c|c|c|}
\hline \multirow{2}{*}{$\begin{array}{c}\text { Concentration } \\
\mathbf{m g} / \mathbf{L}\end{array}$} & $\begin{array}{l}|c| \\
\text { Uncovered vegetative } \\
\text { branches }\end{array}$ & Covered vegetative branches & $\begin{array}{c}\text { Length of vegetative } \\
\text { branches (cm) }\end{array}$ \\
\hline $\mathbf{0}$ & $10 \mathrm{a}$ & Zero d & Zero d \\
\hline $\mathbf{1}$ & $4.375 \mathrm{~b}$ & $5.625 \mathrm{bc}$ & $5.895 \mathrm{a}$ \\
\hline $\mathbf{2}$ & $1.250 \mathrm{~d}$ & $8.750 \mathrm{a}$ & $7.300 \mathrm{a}$ \\
\hline $\mathbf{3}$ & $3.125 \mathrm{c}$ & $6.875 \mathrm{~b}$ & $7.188 \mathrm{a}$ \\
\hline $\mathbf{7}$ & $5.00 \mathrm{~b}$ & $5.00 \mathrm{c}$ & $5.303 \mathrm{a}$ \\
\hline LSD & 1.8 & 1.570 & 3.110 \\
\hline
\end{tabular}

*: Means followed by the same letter are not significantly different according to RLSD at $\mathrm{P} \leq 0.05$.

Rooting in Yucca elephantipes plants:

For initiation and growth of rooting of the vegetative branches developed from apical buds of the plant YUCCA ELEPHANTIPES INDOL BUTYRIC ACID (IBA) WAS USED IN FIVE DIFFERENT CONCENTRATIONS, 0, 0.2, 0.4, 0.6 AND 1 mg / L. Table (3) shows the analysis of variance between different IBA concentrations in number and length of roots in the developed vegetative branches from apical buds of the plant. The results indicated high significant differences between the 5 IBA treatments in the number and length of the initiated roots.

TABLE 3. ANALYSIS OF VARIANCE BETWEEN THE DIFFERENT IBA HORMONE CONCENTRATIONS ON NUMBER OF COVERED AND UNCOVERED VEGETATIVE ROOTS AND THEIR LENGTH SPINELESS YUCCA PLANT

\begin{tabular}{|c|c|c|c|}
\hline Source of variation & DF & Number of roots & Length of roots (cm) \\
\hline Between treatments & 4 & $358.4^{* *}$ & $315.71^{* *}$ \\
\hline Standard error & 35 & 19.91 & 19.42 \\
\hline Total & 39 & & \\
\hline
\end{tabular}

NS: Not significant at $\mathrm{P} \leq 0.05,{ }^{*}$ : significant at $\mathrm{P} \leq 0.05, * *$ : significant at $\mathrm{P} \leq 0.01$

\section{Root number:}

The mean values in table (4) illustrate that IBA concentration of $1 \mathrm{mg} / \mathrm{L}$ gave significantly the highest root numbers reaching 1 roots, seconded by the concentration $0.6 \mathrm{mg} / \mathrm{L}$ with 14 roots with no significant difference between them. And there is no significant differences between the concentrations $0.2,0.4$ and 0.6 in number of roots and they gave 10,10 and 14 roots respectively. 
Root length:

The results in Table (4) show that the IBA concentrations of $1 \mathrm{mg} / \mathrm{L}$ and $0.6 \mathrm{mg} / \mathrm{L}$ gave significantly the highest root lengths of 15.666 and $14.813 \mathrm{~cm}$ respectively without significant difference between them, compared to the other treatments $0,0.2$ and $0.4 \mathrm{mg} / \mathrm{L}$ which gave zero, 8.283 , and $9.500 \mathrm{~cm}$ root length respectively.

TABLE 4. MEANS OF LENGTH OF ROOTS INITIATED FROM VEGETATIVE BRANCHES SPINELESS YUCCA PLANT UNDER DIFFERENT IBA CONCENTRATIONS

\begin{tabular}{|c|c|c|}
\hline $\begin{array}{c}\text { Concentration } \\
(\mathbf{m g} / \mathbf{L})\end{array}$ & Root number & Root length $(\mathbf{c m})$ \\
\hline $\mathbf{0}$ & Zero c & $8.283 \mathrm{~b}$ \\
\hline $\mathbf{0 . 2}$ & $10 \mathrm{~b}$ & $9.5 \mathrm{~b}$ \\
\hline $\mathbf{0 . 4}$ & $19 \mathrm{~b}$ & $14.813 \mathrm{ab}$ \\
\hline $\mathbf{0 . 6}$ & $14 \mathrm{ab}$ & $15.666 \mathrm{a}$ \\
\hline $\mathbf{1 . 0}$ & $18 \mathrm{a}$ & 4.52 \\
\hline LSD & 4.57 & \\
\hline
\end{tabular}

*: Means followed by the same letter are not significantly different according to RLSD at $\mathrm{P} \leq 0.05$.

\section{DISCUSSION}

Plant growth regulators are hormones that initiate and regulate growth in plants, and they are produced naturally by plants normally in shoot and root tips, and these hormones promote cell division and stem and root growth. (Holganix, 2018). The addition of the auxin benzyl adenine (BA) with fixed concentration of NAA to the media of growth of the apical buds of the plant Yucca elephantipes initiated, enhanced and significantly increased number and length of covered vegetative branches. Also addition of the plant growth regulator indole-3-buteric acid IBA) to growth media enhanced and increased root numbers and root lengths of the plant Yucca elephantipes. The results obtained in this study agree with results obtained by many researchers. Shahanaz,et al. (2007) said that N6-benzyl adenine (BA) was the best and more efficient in induction of shoots growth, and under application of $8.87 \mu \mathrm{M}$ BA and $2.46 \mu \mathrm{M}$ indole-3-butyric acid (IBA) to a Murashige and Skoog (MS) medium they obtained the highest number of shoots from leaf and internode explants (76.0 and 90.8 shoots respectively, and within 40 days Calli subcultured onto medium supplemented with $8.87 \mu \mathrm{M}$ BA and $2.46 \mu \mathrm{M}$ IBA developed a mean of 20.1 shoots. And (Enders et al. 2015) said that plant growth regulators help plant development at all levels, from cellular level, through organs, and ultimately to the whole plant. Leyser, 2018 and Enders et al., (2015) administered that dramatic changes occur in gene expression when a plant cell comes into contact with auxin, and regulation takes place in the genes and some genes come up and other genes come down. But the exact mechanisms of this gene arrangement are still under research, but generally there is now a concept of at least two auxin signalling pathways.

And about actions of plant growth regulators on the cellular level (Benkova et al. 2003) mentioned that auxin is essential for cell growth, affecting both cell division and cellular expansion, and that auxin concentration level, together with other factors, causes differentiation and specification of the cell. Enders et al. (2015) said there are receptors that receive auxin and these are proteins like the family of F-box proteins (TIR1/ AFB ), and when these proteins bind to auxin, the auxin acts as a 'molecular glue' that allows these proteins to then bind to their targets whether apical bud tissues or others. On other hand (Friml, 2003) declared that auxin may promote axial elongation as in shoots, or lateral expansion as in root swelling, and it may promotes cellular expansion without cell division depending on the specific tissue. The first action of auxins begins in the embryo in initiating it to form buds, then initiate buds to form organs, then organize the arising organs development like roots, cotyledons and leaves.

Benkova et al. (2003) said that the action of auxins in stimulation of cell elongation comes through their stimulation of the wall-loosening factors, such as elastins, to loosen cell walls. The effect is stronger with presence of gibberellins and cytokinins. In this present research application of IBA up to $1 \mathrm{mg} / \mathrm{L}$ significantly increased root number and root length compared to control. This agrees with the result of Chambers (1999) who found that auxins promote root initiation and induce formation of the adventitious root, thus aiding branching of the roots. In this study it was observed that there are no significant differences between the different IBA concentrations 0.2 , $0.4,0.6$ and $1 \mathrm{mg} / \mathrm{L}$ in root length, and this finding agrees with what Chambers (1999) hasdocumented that high concentrations of auxin inhibit root elongation and instead enhance adventitious root formation. Shahanaz,et al. (2007) said that N6-benzyladenine (BA) was the best and more efficient in induction of shoots growth. Application of 8.87 $\mu \mathrm{M}$ BA and $2.46 \mu \mathrm{M}$ indole-3-butyric acid (IBA) to a 
Murashige and Skoog (MS) medium gave the highest number of shoots from leaf and internode explants (76.0 and 90.8 shoots respectively. Calli subcultured onto medium supplemented with $8.87 \mu \mathrm{M}$ BA and $2.46 \mu \mathrm{M}$ IBA developed a mean of 20.1 shoots within 40 days.

\section{CONCLUSION}

Application of Benzyl adenine (BA) using Murashige and Skoog (MS) medium retarded number of covered branches in terminal buds of the plant Yucca elephentipes compared to the control treatment without BA, but significantly increased number and length of the uncovered branches. Concentrations 2 and $3 \mathrm{mg} / \mathrm{L}$ gave the highest number of vegetative branches 8.75 and 6.876 branches respectively while increasing BA concentration up to $7 \mathrm{mg}$ / $\mathrm{L}$ reduced this maximum result reached by concentrations 2 and $3 \mathrm{mg} / \mathrm{L}$, but for the vegetative branch length there is no significant differences between the IB concentrations 1$7 \mathrm{mg} / \mathrm{L}$ and it ranged between 5.3 and $7.3 \mathrm{~cm}$. As for IBA root number and root length increased with increase in concentration from $0.2,0.4,0.6$ and $1 \mathrm{mg} / \mathrm{L}$, with the highest number of roots (18) and highest root length (15.666 $\mathrm{cm}$ ) given by $1 \mathrm{mg} / \mathrm{L}$ concentration. It is recommended for initiation of vegetative uncovered branch numbers in apical buds of Yucca elephentipes plant to apply BA at rate of up to 2-3 mg / L, and for branch length Ba concentration can rise up to $7 \mathrm{mg} / \mathrm{L}$, while for initiation of root numbers and length IBA can be applied up to $1 \mathrm{mg} / \mathrm{L}$.

\section{REFERENCES}

[1] R. Aloni, E. Aloni, M. Langhans, C.I. Ullrich. "Role of Cytokinin and Auxin in Shaping Root Architecture: Regulating Vascular Differentiation, Lateral Root Initiation, Root Apical Dominance and Root Gravitropism". Annal of Botany, vol. 97, issu. 5: 883-893. 2006.

[2] J.M. Annis, J.E. O’Brien, J.M. Coons, B. "Molano-Flores. Seed Ecology of Federally Threatened Pinguicula ionantha J.M. Godfrey's Butterwort". 1Biological Sciences Department, Eastern Illinois University, Charleston, IL619202, Illinois Natural History Survey, University of Illinois, Champaign, IL 61820. 2014.

[3] E. Benková, M. Michniewicz, M. Sauer. "Local, efflux-dependent auxin gradients as a common module for plant organ formation”. Cell. 115 (5): 591-602. 2003.

[4] P. Chambers. "Science and Technology Dictionary". ISBN 978-0-55014110-1. 1999

[5] Enders Tara, C. Strader Lucia. "Auxin Activity: Past, present, and Future". American Journal of Botany. 102 (2):180-196. 2015.

[6] J. Friml. "Auxin transport-shaping the plant". Holganix and the leaf symbol are registered trademarks of Holganix, Inc. 3033 Market St., Aston, PA, 19104 , Current Opinion in Plant Biology. 6 (1): 7-12. PMID 12495745. 2003.

[7] O. Leyser. "Auxin Signaling". Plant Physiology". 176 (1): 465479. 2018.

[8] J. Ludwig-Müller. "Auxin conjugates: their role for plant development and in the evolution of land plants". J. Exp. Bot. 62 (6): 1757-1773. 2011.

[9] B.A. Shahanaz, M. K. Poulose, Z. Chun-Lai, I. Nishitha, K. Ligimol, S Adrian, P.V. Madhusoodanan. "Organogenesis from leaf and internode explants of Ophiorrhiza prostrata, an anticancer drug (camptothecin) producing plant". Electronic Journal of Biotechnology, vol. 10 (1): pp. 110. 2007.

[10] Simon, S; Petrášek, P (2011). "Why plants need more than one type of auxin". Plant Science. 180 (3): 454-460.

[11] Y.H. Wang, J. Liu, B. Chen, Z.G. Zhou. "Physiological mechanisms of growth regulators 6-BA and $\mathrm{ABA}$ in mitigating low temperature stress of cotton fiber development”. Ying Yong Sheng- TaiXue Bau, vol. 22(5):pp. 1233-9. 2011. 